\title{
Research
}

\section{A survey of Indonesian otolaryngologist behavior in medical service during the CoVid-19 pandemic}

\author{
Indra Zachreini', Jenny Bashiruddin ${ }^{2}$, Susyana Tamin², Harim Priyono², \\ Ika Dewi Mayangsari², Respati Ranakusuma², Natasha Supartono ${ }^{2}$,
} Fikri Mirza Putranto ${ }^{3}$, Dewo Aksoro ${ }^{4}$, Selfiyanti Bimantara ${ }^{5}$, Yussy Afriana Dewi ${ }^{6}$, Kote Noordhianta ${ }^{7}$, Bintang Napitupulu ${ }^{8}$, Sagung Rai Indrasari ${ }^{9}$, Nyilo Purnami ${ }^{10}$, Tengku Siti Hajar Haryuna ${ }^{11}$, Juliandi Harahap ${ }^{11}$, Eka Savitri ${ }^{12}$, Tjandra Manukbua ${ }^{13}$

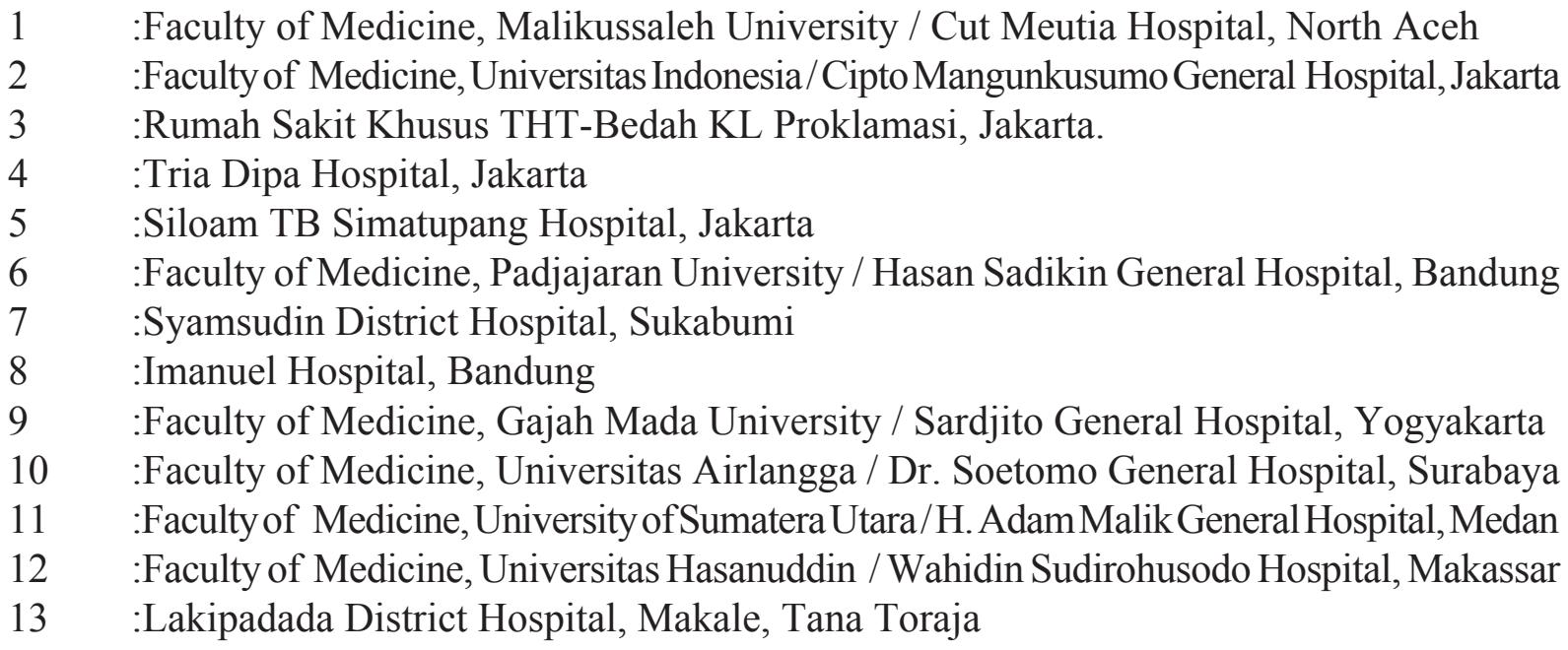

\begin{abstract}
Background: World Health Organization (WHO) announced a newly discovered virus that first identified in Wuhan, China on December 2019, namely SARS-CoV-2 as the cause of corona virus disease (COVID-19) which had become global pandemic. Doctors as medical practitioners are categorized as vulnerable group to be infected by corona virus, and many otorhinolaryngologists had been infected and even died in performing medical services. Among the causative factors why otorhinolaryngologists could get infected by corona virus is their behavior. Purpose: To assess the behavioral level of otorhinolaryngologists in medical services during Covid-19 pandemic. Method: Descriptive study with a cross sectional design. Research samples were otorhinolaryngologists in Indonesia who met the inclusions criteria. The samples were selected by consecutive sampling method, and obtained 1299 subjects. Behavioral level was assessed from 3 aspects: knowledge, attitude, and practice, which comprised of 12 questions. Result: It was found that 461 respondents had a good behavioral level (35.5\%), 677 respondents had moderate levels $(52.1 \%)$ and 161 respondents had low level (12.4\%). There was a statistically significant correlation between knowledge with behavioral level, attitude with behavioral level, and practice with behavioral level $(p=0.001)$. Conclusion: The study of behavioral level of otorhinolaryngologists in medical service during Covid-19 pandemic obtained the highest number was moderate level 677 respondents $(57.2 \%)$, and there was a statistically significant correlations between the variable of knowledge with behavioral level, the variable of attitude with behavioral level, and the variable of practice with behavioral level $(p=0.001)$.
\end{abstract}

Keywords: behavioral level, otorhinolaryngologist, pandemic, Covid-19 


\section{ABSTRAK}

Latar belakang: Organisasi kesehatan dunia (WHO) mengumumkan virus baru yang pertama kali muncul di Wuhan China, pada Desember 2019, yaitu SARS-CoV-2 sebagai penyebab corona virus disease 19 (Covid 19) dan menyatakan sebagai pandemi. Dokter sebagai tenaga kesehatan merupakan kelompok yang rentan terinfeksi virus corona dan berdasarkan laporan, sudah banyak dokter Telinga Hidung Tenggorok - Bedah Kepala Leher (THT-KL) yang terinfeksi bahkan meninggal dunia dalam pelayanan medis. Salah satu faktor penyebab dokter THT-KL terinfeksi oleh virus corona adalah tingkat perilaku dokter THT-KL. Tujuan: Mengetahui tingkat perilaku dokter THT-KL dalam melakukan pelayanan medis saat pandemi Covid 19. Metode: Penelitian deskriptif dengan rancangan studi potong lintang. Sampel penelitian adalah dokter THT-KL di Indonesia yang memenuhi kriteria inklusi. Teknik pengambilan sampel secara berurutan, dan mendapatkan 1299 sampel. Tingkat perilaku dinilai dari 3 aspek yaitu dimulai dari pengetahuan, sikap dan tindakan yang terdiri dari 12 pertanyaan. Hasil: Didapatkan tingkat perilaku responden dokter THT-KL dalam pelayanan medis pada pandemi Covid 19, tingkat perilaku baik sebanyak 461 responden (35,4\%), tingkat sedang 677 responden $(52,1 \%)$, dan tingkat kurang 161 responden (12.4\%). Terdapat hubungan yang signifikan antara pengetahuan dan tingkat perilaku, sikap dengan tingkat perilaku dan tindakan dengan sikap perilaku $(p=0,001)$. Kesimpulan: Didapatkan tingkat perilaku dokter THT-KL dalam pelayanan medis pada pandemi covid 19, terbanyak adalah tingkat perilaku sedang sebanyak 677 responden $(57,2 \%)$, dan terdapat hubungan yang bermakna antara variabel pengetahuan dengan tingkat perilaku, variabel sikap dengan tingkat perilaku dan variabel tindakan dengan tingkat perilaku dokter THT-KL dalam pelayanan medis pada pandemi Covid 19, dimana nilai $p=0,001$.

Kata kunci: perilaku, dokter THT-KL, pandemic, Covid-19

Correspondence address: Dr. dr. Indra Zachreini,Sp.THT-KL(K), FISCM, KMF Ilmu Kesehatan THTKL FK Universitas Malikussaleh/RS. Cut Meutia Aceh Utara, Jln. Medan Banda Aceh Km 6 Bukit Rata Lhoksumawe Aceh.Email: indrazachreini@unimal.ac.id.

\section{INTRODUCTION}

Behaviour is the kind of response or reaction of a person to external stimulus. The response to the same stimulus could be different in each individual. It is influenced by the character of the person and other factors. The factors that generate different response to the same stimulus is named behavioral determinant, which is divided into internal determinant and external determinant. Internal determinant is the characteristic of the person such as level of intelligence, level of emotional, gender, etc. External determinant is the environment of the person including physical environment, social, economy, politic, et cetera. Bloom (1908) categorized human behavior into 3 domains: cognitive, affective, and psychomotor. In evolution the Bloom theory was modified into knowledge, attitude and practice. ${ }^{1}$
On March 12, 2020 the World Health Organization (WHO) officially announced the global pandemic of COVID-19. A newly discovered virus that first identified in Wuhan, China on December 2019, namely SARS-CoV-2 was the cause of corona virus disease (COVID-19). ${ }^{2}$ Indonesian government also declared on February 14, 2020 with Permenkes No. HK 01.07/ Menkes/104/2020 that COVID-19 had become a medical emergency in Indonesia. ${ }^{3}$ On March 21, 2020 the Indonesian government declared COVID-19 as a Public Health Emergency, according to Keppres No.11 tahun $2020 .{ }^{4}$ On May 2020 The Indonesian Otorhinolaryngological Head Neck Surgery Association also published a handbook concerning the management in ENT and Head Neck services during COVID-19 pandemic, ${ }^{5}$ and a handbook about adaptation to the new routine in ENT and Head Neck services during COVID-19 pandemic era. ${ }^{6}$ 
Doctors as medical practitioners are categorized as vulnerable group to be infected by corona virus, especially otorhinolaryngologists, since in daily practice they often contact with corona virus through the respiratory tract, particularly the nose, as the highest viral load is in the nasal passage. High concentration of COVID-19 in the nasal passages is associated with increased risk of more severe disease and death. ${ }^{7,8}$ Many otorhinolaryngologists had been infected and even died in performing medical services. The first fatality of a physician documented globally was that of an otolaryngologist in Wuhan, China on January, 252020 and the total mortality number was the highest in the world. ${ }^{9}$ Even though the Indonesian government had launched the regulation to protect the health workers with Permenkes No. 66/2016, about the occupational health and safety in hospital and the obligatory to wear personal protective equipment (PPE) as a standard precaution and risk control, the death of otorhinolaryngologists still occurred..$^{10}$ Mitigation report from the Indonesian Doctors Association (PB IDI) on 10.00 a.m March, 21, 2021 announced that in COVID-19 pandemic there were 325 doctors had perished, 10 of them were otorhinolaryngologists. ${ }^{11}$

There are several factors that facilitate the COVID-19 viral transmission, such as the lack of PPE, age, comorbidities, and behavioral factor of the person. The Indonesian Otorhinolaryngological Head Neck Surgery Association conducted a research to find out the behavioral level of otorhinolaryngologists in Indonesia in performing medical services during COVID-19 pandemic.

\section{METHOD}

This was a descriptive analytic study with a cross sectional method. The sample study was otorhinolaryngologists in Indonesia who met the inclusion criteria. The inclusion criteria were otorhinolaryngologists who already had a Registration Certificate from Indonesian Medical Council, performing ENT medical service, and willing to participate in the study.

The target population of this study was Otorhinolaryngologists who were registered as the member of The Indonesian Otorhinolaryngology Head and Neck Surgery Society, totally as many as 1657 doctors. The samples were selected by consecutive sampling method, and obtained 1299 subjects. Data collection was performed by filling a questionnaire list through the google form. Research period was 3 months (June-August, 2020), including preparing the proposal until processing the result.

The behavioral level was assessed from 3 aspects: knowledge, attitude, and practice, which comprised of 12 questions. Each aspect of respondent's choice was scored according to the highest number of correct answers.

The score of behavioral level was good if the correct answer was more than $75 \%$, the level was moderate if the correct answer was $50-75 \%$, and the level was poor if the correct answer was less than $50 \%$. In this study, the correlation between the variable of knowledge, the variable of attitude, and the variable of practice with behavioral level was analyzed using chi-square test with significance value $\alpha<0.05$.

\section{RESULT}

From this study we obtained univariate data including mean, median, mode and standard deviation of age and gender of the respondents. (Table 1)

Table 1 showed the mean age of the respondents was $46.85 \pm 11.243$, with median value 44.0 years. The frequency distribution of the variable of knowledge, attitude and action of the respondents were presented in Table 2. 
Table 1. Characteristic of respondents

\begin{tabular}{lc}
\hline \multicolumn{1}{c}{ Characteristic } & Total $(\mathbf{n}=\mathbf{1 2 9 9})$ \\
\hline Mean age (years) & 46.85 \\
Median age (years) & 44.00 \\
Mode age (years) & 36.00 \\
Age standard deviation (years) & 11.243 \\
Minimal age (years) & 30 \\
Maximal age (years) & 88 \\
Female (\%) & 49,00 \\
Male (\%) & 51,00 \\
\hline
\end{tabular}

Tabel 2. The frequency distribution of the variable of knowledge, attitude, action and behavioral level of the respondents

\begin{tabular}{|c|c|c|}
\hline Behavioral level & $\mathbf{n}$ & $\%$ \\
\hline \multicolumn{3}{|l|}{ Knowledge } \\
\hline Good & 1032 & 79.4 \\
\hline Moderate & 216 & 16.6 \\
\hline $\mathrm{Bad}$ & 51 & 3.9 \\
\hline \multicolumn{3}{|l|}{ Attitude } \\
\hline Good & 252 & 19.4 \\
\hline Moderate & 639 & 49.2 \\
\hline $\mathrm{Bad}$ & 408 & 31.4 \\
\hline \multicolumn{3}{|l|}{ Practice } \\
\hline Good & 1225 & 94.3 \\
\hline $\mathrm{Bad}$ & 74 & 5.7 \\
\hline \multicolumn{3}{|l|}{ Behavioral level } \\
\hline Good & 461 & 35.5 \\
\hline Moderate & 677 & 52.1 \\
\hline Low & 161 & 12.4 \\
\hline
\end{tabular}

In the behavioral level assessment of otorhinolaryngologist in medical service during the CoVid-19 pandemic in Indonesia, we obtained the highest number in variable of knowledge of the respondents was good level, as many as 1032 respondents (79.4\%). The highest number in variable of attitude was moderate level as many as 639 respondents $(49.2 \%)$, followed by low level as many as 408 respondents $(31.4 \%)$, and the highest number in variable of practice was good level as many as 1225 respondents $(94.3 \%)$.

The behavioral level distribution of the respondents could also be seen in Table 2 . The highest number obtained was moderate level 677 respondents $(57.2 \%)$, followed by good level 461 respondents $(35.5 \%)$.
Based on the above results, assessment of the correlation between the variable of knowledge with behavioral level, the variable of attitude with behavioral level, and the variable of practice with behavioral level was performed and the result was shown in Table 3.

There was a statistically significant correlations between the variable of knowledge with behavioral level, the variable of attitude with behavioral level, and the variable of practice with behavioral level of otorhinolaryngologists in medical service during Covid-19 pandemic ( $\mathrm{p}=0.001)$. 
Tabel 3. The correlation between variable of knowledge, attitude and practice with behavioral level of respondents

\begin{tabular}{|c|c|c|c|c|c|c|c|}
\hline & \multicolumn{6}{|c|}{ Behavioral level } & \multirow{3}{*}{$\mathbf{p}$} \\
\hline & \multicolumn{2}{|c|}{ Good } & \multicolumn{2}{|c|}{ Moderate } & \multicolumn{2}{|c|}{ Low } & \\
\hline & $\mathrm{n}$ & $\%$ & $\mathrm{n}$ & $\%$ & $\mathrm{n}$ & $\%$ & \\
\hline \multicolumn{8}{|l|}{ Knowledge } \\
\hline Good & 420 & 40.7 & 529 & 51.3 & 83 & 8.0 & \\
\hline Moderate & 36 & 16.7 & 122 & 56.5 & 58 & 26.9 & 0.001 \\
\hline Bad & 5 & 9.8 & 26 & 51.0 & 29 & 39.2 & \\
\hline \multicolumn{8}{|l|}{ Attitude } \\
\hline Good & 242 & 96.0 & 10 & 4.0 & 0 & 0.0 & \\
\hline Moderate & 219 & 34.3 & 417 & 65.3 & 3 & 0.5 & 0.001 \\
\hline $\mathrm{Bad}$ & 0 & 0.0 & 250 & 61.3 & 158 & 38.7 & \\
\hline \multicolumn{8}{|l|}{ Practice } \\
\hline Good & 454 & 37.1 & 636 & 51.9 & 135 & 11.0 & \\
\hline $\mathrm{Bad}$ & 7 & 9.5 & 41 & 55.4 & 26 & 35.1 & 0.001 \\
\hline
\end{tabular}

\section{DISCUSSION}

The survey found that the level of knowledge of Indonesian otorhinolaryngologists about Covid-19 was good (79.4\%), the attitude in dealing problems in Covid pandemic were moderate level (49.2), and the practice in medical services during Covid pandemic was good level (94.3\%). Based on those three components, it could be concluded that the highest behavioral level of Indonesian otorhinolaryngologists in medical services during Covid pandemic was moderate level (52.1\%), followed by good behavioral level $(35.5 \%)$, and the least was bad behavioral level (12.4\%).

As the result of this survey, the highest number of behavioral level of Indonesian otorhinolaryngologists in medical services during Covid pandemic was moderate level. This was established based on their knowledge of the etiology, mode of transmission of corona virus, and the knowledge of selfprotection against corona virus transmission. Furthermore, how was the practice of the otorhinolaryngologists in dealing with patients, such as at moments when he had to do nasopharyngeal swab, what to do when the appropriate PPE was lacking, how to collaborate with fellow doctors in taking care of positive Covid patients, and what to do in performing daily elective surgeries, etc. Last but not least, did the respondents keep on performing the medical examination in such a situation when there was lack of the PPE.

A correlation test was performed between the variable of knowledge with behavioral level, variable of attitude with behavioral level, and variable of practice with behavioral level in performing medical services during COVID-19 pandemic, and the result established there was a significant correlation between those three components with behavioral level $(p=0.001)$

The reason that medical personals could get infected by SARS CoV2 in the first place was because of their low awareness in controlling infection spread at the beginning of COVID-19 pandemic, and especially among the otorhinolaryngologists compared to other doctors in the same hospital. ${ }^{12-14}$

Otorhinolaryngologists have greater risks getting viral infection coming from the respiratory tract secretion or aerosol droplets when examining the patients, so they are expected to improve their knowledge and behavior. ${ }^{15}$ Better behavior was mandatory to avoid corona virus contamination during the COVID-19 pandemic. 
Up till now, there was no publication yet concerning the behavior of otorhinolaryngologists in medical services during COVID-19 pandemic. In 2020, Shi et al. ${ }^{16}$ reported their study about the knowledge and attitude of psychiatrists and psychiatric nurse in 2 mental hospital in China. The results were among 141 psychiatrists and 170 psychiatric nurses in those hospitals, $89.51 \%$ of them had a good knowledge about the COVID-19, and $77.71 \%$ had an earnest attitude in doing medical services for the mentally ill patients. Mae et al. ${ }^{17}$ (2011) reported that during H1N1 influenza pandemic in the year 2009 that $82.3 \%$ of medical staffs in the intensive care unit (ICU) expressed willingness to care for H1N1 patients, but that influenza pandemic was not as infectious as COVID-19.

Amin et al. ${ }^{18}$ (2020) reported the result of his study concerning the knowledge of 220 medical doctors who worked in the frontline taking care of COVID-19 patients, was mostly high level (56.56\%). They assessed the knowledge according to questionnaires they made about the diagnosis test for COVID-19, the risk factors, the complication and the mortality of COVID-19 cases, and their knowledge about PPE. The answers were scored with total value 7, where 6-7 was high, 4-5 was moderate, and less than 4 was low.

The conclusion of this study was the highest number of behavioral level of Indonesian otorhinolaryngologists in medical services during Covid-19 pandemic was moderate level as many as 677 respondents (57.2\%). There was a significant correlation between the variable of knowledge with behavioral level, variable of attitude with behavioral level, and variable of practice with behavioral level in performing medical services during COVID-19 pandemic $(p=0.001)$. Our recommendation for the next study is assessing the variables of knowledge, attitude, and practice using the standard parameters.
We hope that this report could uplift the awareness of the Indonesian otorhinolaryngologists, and encourage them to improve their knowledge, attitude and practice in medical services during COVID-19 pandemic. We also suggest that our fellow Indonesian otorhinolaryngologists frequently attend the webinars about COVID-19, and read the Indonesian manual book published by The Indonesian Otorhinolaryngological Head Neck Surgery Association concerning the management and adaptation of the new rutine in ENT and Head Neck services during COVID-19 pandemic, and apply that in their daily practices.

\section{REFERENCE}

1. Notoatmodjo S. Promosi kesehatan dan perilaku kesehatan. Jakarta: Rineka Cipta; 2020. p.131-47.

2. World Health Organization. WHO directorgeneral's opening remarks at the media briefing on COVID-19. [Internet]. 2020. Available from: https://www.who.int/ director-general/speeches/detail/whodirector-general-s-opening-remarks-atthe-media-briefing-on-covid-19---11march-2020.

3. Menkes RI. PERMENKES No.7 HK 01.07/Menkes/104/2020 tentang Penetapan Infeksi Novel Coronavirus (Infeksi 2019-nCoV) Sebagai Penyakit yang Dapat Menimbulkan Wabah dan Upaya Penanggulangannya [Internet]. Available from: http://hukor.kemkes.go.id/uploads/ produk hukum/KMK_No HK_01_07MENKES-104-2020 ttg Penetapan Infeksi_Novel_Coronavirus_Penyakit Yang_Dapat_Menimbulkan_Wabah_pdf.

4. Pemerintah Pusat. KEPPRES No. 11 Tahun 2020 tentang Penetapan Kedaruratan Kesehatan Masyarakat Corona Virus Disease 2019 (COVID-19) [Internet]. 2020. Available from: https://peraturan.bpk.go.id/Home/ Details/135058/keppres-no-11-tahun-2020

5. Bashiruddin J, Soekin S, Adham M, Dewi YA. Buku Pedoman Tatalaksana di Bidang T.H.T.K.L. Selama Pandemi Covid-19. Jakarta: PERHIMPUNAN 
DOKTER SPESIALIS TELINGA HIDUNG TENGGOROK BEDAH KEPALA LEHER INDONESIA. PERHATI KL; 2020.

6. Bashiruddin J, Soekin S, Adham M, Dewi YA. Adaptasi Kebiasaan Baru dalam Pelayanan T.H.T.K.L. di Era Pandemi Covid-19. Edisi ke 2. Jakarta: PERHIMPUNAN DOKTER SPESIALIS TELINGA HIDUNG TENGGOROK BEDAH KEPALA LEHER INDONESIA. PERHATI KL; 2020.

7. Mick P, Murphy R. Aerosol-generating otolaryngology procedures and the need for enhanced PPE during the COVID-19 pandemic: a literature review. J Otolaryngol Head and Neck Surgery. 2020; 49(29): 1-10.

8. Zou L, Ruan F, Huang M, Liang L, Huang $\mathrm{H}$, Hong Z, et al. SARS-CoV-2 Viral Load in Upper Respiratory Specimens of Infected Patients. N Engl J Med. 2020; 382(12):11779.

9. Chan JYK, Wong EWY, Lam W. Practical Aspects of Otolaryngologic Clinical Services During the 2019 Novel Coronavirus Epidemic. An Experience in Hong Kong. JAMA. Otolaryngol Head Neck Surg. 2020; 146(6): 519-20.

10. Menkes RI. Permenkes No. 66/2016 tentang keselamatan dan kesehatan kerja Rumah Sakit [Internet]. 2016. Available from: http:// kesjaorkemkes.go.id/documents/PMK No. 66 ttg_Keselamatan_dan_Kesehatan _ Kerja_Rumah_Sakit_pdf

11. Tim Mitigasi IDI. Update kematian kasus COVID-19 dokter di Indonesia. 7 Maret 2021. https://instagram.com/timmitigasiidi ?igshid $=13 \mathrm{nd} 69 \mathrm{es} 28 \mathrm{rp} 1$

12. Wang D, Hu B, Hu C, Zhu F, Liu X, Zhang J, et al. Clinical characteristics of 138 hospitalized patients with 2019 novel coronavirus-infected pneumonia in Wuhan, China. JAMA. 2020; 323(11): 1061-9.

13. Wu Z, McGoogan JM. Characteristics of and important lessons from the coronavirus disease 2019 (COVID-19) outbreak in China: summary of a report of 72314 cases from the Chinese Center for Disease Control and Prevention. JAMA. 2020; 323(13): 1239-42.

14. Patel ZM, Fernandez-Miranda J, Hwang PH, Nayak JV, Dodd R, Sajjadi H, et al. Letter: Precautions for endoscopic transnasal skull base surgery during the COVID-19 pandemic. Neurosurgery. 2020; 87(1): E66-7.

15. Tran K, Cimon K, Severn M, PessoaSilva CL, Conly J. Aerosol generating procedures and risk of transmission of acute respiratory infections to healthcare workers: a systematic review. PLoS ONE. 2012; 7(4): e35797.

16. Shi Y, Wang J, Yang Y, Wang Z, Wang G, Hashimoto $\mathrm{K}$ et al. Knowledge and attitudes of medical staff in Chinese psychiatric hospitals regarding COVID 19. Brain, Behav Immun. 2020; 100064.

17. Ma X, He Z, Wang Y, Jiang L, Xu Y, Qian C, et al., and The China Critical Care Clinical Trial Group (CCCCTG). Knowledge and attitudes of health care workers in Chinese intensive care units regarding 2009 H1N1 influenza pandemic. BMC Infect. Dis. 2011; 11(1): 24.

18. Amin F., Sharif S., Saeed R., Durrani N., and Jilani D. COVID-19 pandemicknowledge, perception, anxiety, and depression among frontline doctors of Pakistan. BMC Psychiatry. 2020; 20(459): 1-9. 